\title{
Amend Patent Legislation to Expand Access to Pharmaceuticals during National Emergencies
}

\author{
Aya W. Takai ${ }^{1}$, Samuel B. Lum ${ }^{2}$ \\ 1 University of Michigan, School of Public Health, Ann Arbor, MI \\ ${ }^{2}$ Rochester Institute of Technology, Department of Biomedical Sciences, Rochester, NY \\ https://doi.org/10.38126/ISPG180113 \\ Corresponding author: awtakai@umich.edu \\ Keywords: patent legislation; patent extension; coronavirus; national emergency
}

\begin{abstract}
Executive Summary: As of February 2021, the COVID-19 pandemic has led to almost 109 million cases worldwide and over 486,000 American deaths (Johns Hopkins University 2021). With the federal government pouring more than $\$ 9$ billion in taxpayer money to develop vaccines and treatments for COVID-19, accessibility to these taxpayer-funded products is a public concern (Witters 2020). Under current U.S. law, private entities of any size are allowed to keep patents funded by taxpayer dollars (Stevens 2004). Although government use of taxpayer funded patents exist in limited circumstances, there is little incentive beyond public and political pressure for pharmaceutical companies to forgo patent enforcement for public good. We recommend that Congress amend Title 35 of United States Code to allow patent term extensions when a patent holder agrees to forgo patent enforcement in times of presidentially declared public health national emergencies under the National Emergency Act.
\end{abstract}

\section{Background}

In the wake of the COVID-19 pandemic, the United States government awarded drug companies over $\$ 9$ billion to develop COVID-19 vaccines and treatments (Weintraub and Weise 2020). Under the Bayh-Dole Act and Executive Order 12591 signed by President Ronald Reagan, large pharmaceutical companies are able to keep patents that were developed using taxpayer funds (Schacht 2009). As a result, taxpayer funded patents on COVID-19 vaccines would be held privately, sparking controversy around U.S. taxpayer dollars funding patents that will profit companies. At a House Committee on Energy and Commerce hearing on July 21, 2020, executives from four major pharmaceutical companies testified that they will not sell a potential COVID-19 vaccine at cost, sparking Democratic lawmakers to argue for provisions against pharmaceutical companies profiteering off of research funded by taxpayers (Wu 2020; House Committee on Energy and Commerce 2020).

Although there are avenues for the taxpayer funded patents to be used by the government, these avenues solely rely on the executive branch and the politics of a presidential administration. For example, under the
Bayh-Dole Act, the federal government may require the patent holder to grant a nonexclusive, partially exclusive, or exclusive license under limited circumstances. However, the federal government has yet to invoke these rights under the Bayh-Dole Act (Thomas 2016). The executive branch can also claim government patent use, where the Department of Health and Human Services (HHS) pays the patent holder a royalty in return for buying the drug from any company that can produce it (Kapczynski, Biddinger, and Walensky 2020). The executive branch's use of executive action often varies based on political views and agendas of each presidential administration. For example, the Trump administration delayed and limited the implementation of the Defense Production Act, a similar executive action, despite support from state and local elected officials. Whereas the Biden administration invoked the same executive action within the first week of taking office (Lawson and Rhee 2020; Feuer 2021).

A potential solution to this problem would be to create alternative route to incentivize 
pharmaceutical companies to forgo patent enforcement for the public good. This memo proposes a potential policy solution to incentivize pharmaceutical companies to voluntarily forgo patent enforcement in times of national public health emergencies in exchange for a patent term extension.

II. Impact of patents on public health Since the passage of the first Patent Act of 1790, Congress has expanded patent laws in Title 35 of U.S. Code with an intent to propagate innovation and increase economic capacity. The pharmaceutical industry claims that patents fulfill Congress' intent by incentivizing investment into research and development (R\&D) and recovering upfront costs (PhRMA n.d.). However, current patent law and patents have enabled the profitization of health, creating a number of public health concerns.

\section{i. Profitization of health}

Current patent laws enable patent holders to maximize profit by gaming the patent system (Initiative for Medicines Access and Knowledge 2018). Although patent terms on a single patent are for 20 years, companies can use a tactic called "evergreening." This is when companies file multiple patents on variations or secondary features of the same drug to effectively prolong the total patent period on the same product. Companies can also create "patent thickets," by filing numerous patents on the same product to disincentivize generic drug manufacturers from entering the market for fear of infringement (Richards, Hickey, and Ward 2020). For example, the pharmaceutical company, AbbVie holds about 136 patents on one of the world's top selling drugs, Humira. This has blocked competitors from entering the market and has allowed AbbVie to protect its sales of Humira. These loopholes extend market monopolies, prevent generic drug manufacturers from entering the market, and allow patent holders to continue charging inflated prices for their products without competition (Richards, Hickey, and Ward 2020). When paired with the relative inelasticity of demand for medicine, monopolies in the pharmaceutical industry have contributed to rising drug costs and supply issues.

\section{ii. Rising drug costs}

Limited competition among pharmaceutical companies, weak drug price negotiation powers in the U.S. healthcare system, and lack of price controls, have all led to stronger monopolies and bargaining powers for pharmaceutical patent holders than in other developed countries (Haeder 2019; U.S. Department of Health and Human Services 2018). The House Committee on Ways and Means found that on average, Americans pay up to 67 times more for the same drug compared to consumers in similar high-income countries (Ways and Means Committee Staff 2019). This has led to a major public health concern with almost one third of Americans saying that they did not take their prescription drugs as prescribed in the last year because of costs (Kaiser Family Foundation 2020).

Combined with the COVID-19 pandemic, rising drug prices poses a time-sensitive public health issue. For example, Gilead Sciences announced on June 29, 2020 that they will set U.S. prices for Remdesivir, an antiviral used to treat COVID-19, between $\$ 2,340$ and $\$ 3,120$ per treatment course depending on health insurance coverage (O'Day 2020). In comparison, Remdesivir will be available in low- and middleincome countries for less than a quarter of the price (Inserro 2020). Even though it is reported that U.S. taxpayers contributed over $\$ 70$ million toward its development, the major price difference arises out of Gilead's monopoly of Remdesivir in the United States while allowing generic drug manufacturers to produce and distribute in low- and middle-income countries. Recent polling from Gallup found that 9 in 10 Americans are concerned about rising drug costs due to the pandemic, showing there is public support for legislative intervention (Witters 2020).

\section{iii. Supply issues}

In May 2020, the United States Patent and Trademark Office (USPTO) announced that they will expedite COVID-19-related patents for the next year (U.S. Patent and Trademark Office 2020a; Government Publishing Office 2020). Through this agency policy, COVID-19-related products have been patented and released into the market in a timely manner.

However, supply problems have persisted as demand for COVID-19 related pharmaceuticals have stayed high. Patented drugs are almost always produced by a single source, making the market vulnerable to unexpected shortfalls (Lee Ventola 2011). In the case of Remdesivir, Gilead is already experiencing supply problems in the United States, even though the United States bought all of the world's supply of Remdesivir between July and September of 2020. 
III. Legislative history of patent extensions Towards the end of the Stagflation of the 1970s, Congress and the Carter administration looked towards amending patent law as a means to manage government invested $R \& D$ and stimulate the economy (Stevens 2004). After much political deliberation, the Bayh-Dole Act passed by the 96th Congress in 1980 intended to do just that, by permitting universities and small businesses to retain ownership of patents developed through federally funded research (Schacht 2009). This right was later expanded to large companies by the Reagan administration through executive order 12591, resulting in large pharmaceutical companies including Gilead to be entitled to patents funded by taxpayers (National Archives 2016). The federal government is not entitled to these taxpayer-funded patents unless march-in rights are invoked under limited circumstances. Presently, the federal government has yet to invoke these rights under the Bayh-Dole Act (Thomas 2016).

Under the Uruguay Rounds Agreement Act of 1995, patents have a 20-year term from the date of the initial patent application filing. However, the average pendency time for pharmaceuticals is over 22 months and patents for products regulated under the Federal Food, Drug, and Cosmetic Act and the Public Health Service Act must undergo additional safety requirements (U.S. Food and Drug Administration 2020; U.S. Patent and Trademark Office 2020b). In order to reconcile long approval processes with a limited term period, Congress passed The Drug Price Competition and Patent Term Restoration Act, also known as the Hatch-Waxman Act, in 1984 (Congressional Research Service 2016). Under Title II, patent holders who have experienced lost patent time due to a prolonged approval process under the Federal Food, Drug, and Cosmetic Act and the Public Health Service Act, may recover up to five years by petitioning for a patent term extension (U.S. Congress 1984).

\section{Policy recommendation}

We recommend that Congress amend title 35 of United States Code, to permit patent term extensions when a patent holder agrees to forgo patent enforcement in times of presidentially declared public health national emergencies under the National Emergency Act (NEA). This would create a "patent pause" period in which patent holders may forgo enforcement of the patent in return for a patent term extension of equivalent or greater length on the corresponding patent.

\section{i. Advantages}

This policy proposal may provide all stakeholders with benefits, as shown in Figure 1. Furthermore, the policy would address prioritization of health, rising drug costs, and supply issues.

\section{Prioritization of health}

The policy proposed would incentivize pharmaceutical companies to forgo enforcing patents during times of national emergencies for public benefit. This would codify a system in which a monopoly created by a patent may be temporarily removed.

\section{Rising drug costs}

Temporarily removing the monopoly may stimulate competition, stabilize prices, and expand accessibility of products during the "patent pause" period. Prices may increase after the "patent pause" period and for the length of the patent term.

\section{Supply}

Temporarily removing a monopoly would induce generic drug manufacturers to produce products during the "patent pause" period, diversifying sources.

\section{ii. Disadvantages}

\section{Cost of producing generics}

Depending on initial up-front costs in producing the product, generic drug manufacturers may find that entering the market during the time-limited patent pause may not be financially worthwhile. In such scenarios, government patent use may be an alternative action. 


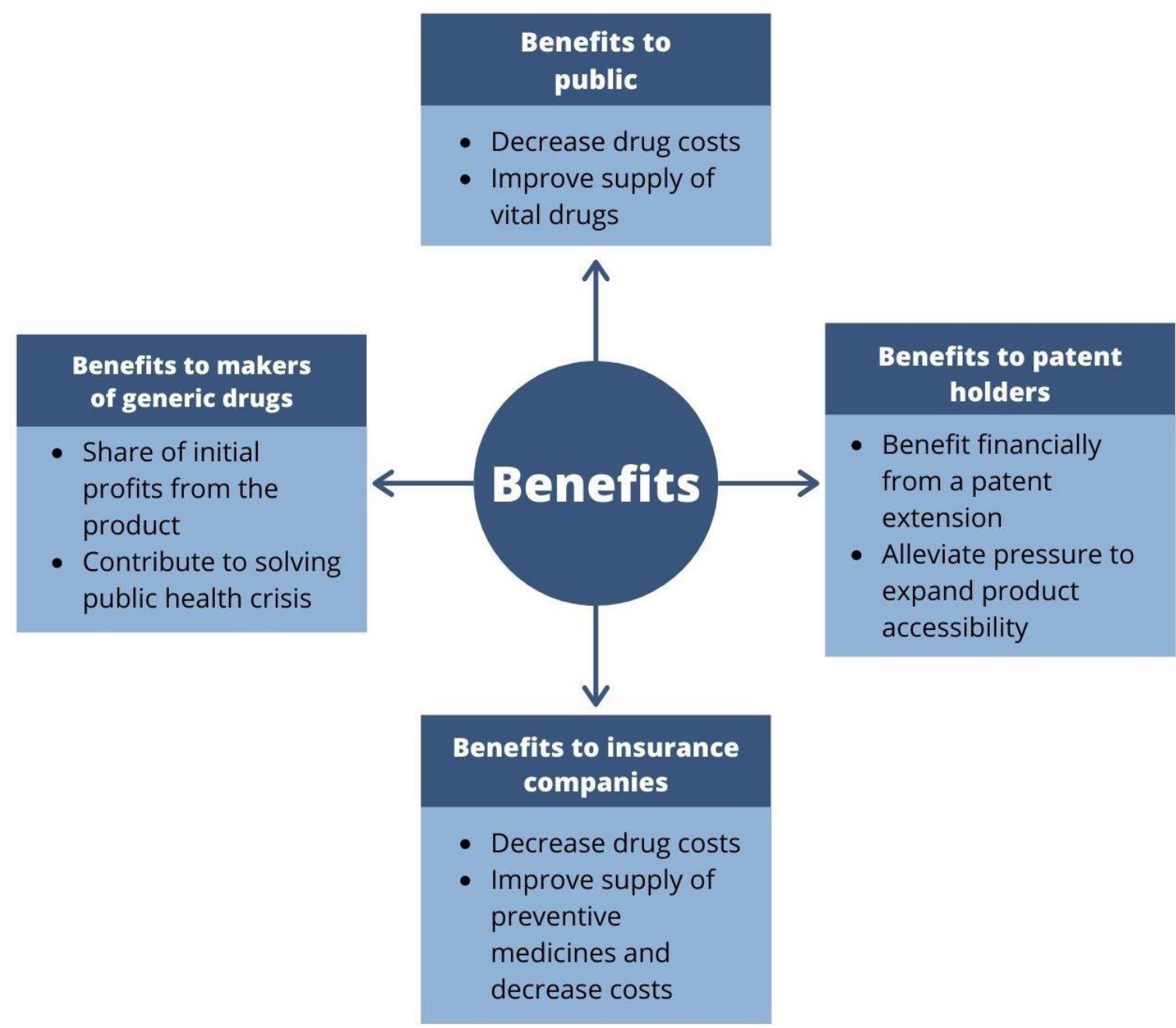

Figure 1. Benefits provided to stakeholders under proposed legislation

Cost to patent holders

Considering the profitability of patents peaks at the beginning of the term, patent holders may experience more loss during the "patent pause period" than they will be able to gain through the extension. This would be the case if the COVID-19 vaccine is effective indefinitely after one course. However, if the vaccine must be administered on a yearly basis like the flu vaccine, profit loss may be prevented.

\section{Political barriers}

Historical attempts to amend patent extensions have been politically unsuccessful because of benefits towards large pharmaceutical companies and burdens on generic drug manufacturers (Schacht and Thomas 2006; Lueck 2005). As with any legislation balancing public and private interests, similar arguments may arise.

\section{Considerations and conclusion}

Congress may consider the following negotiation points between stakeholders when considering this policy proposal. These negotiation points may be helpful for Congressional staff when drafting the bill, collecting endorsements from stakeholders, and soliciting co-sponsorships from Members of Congress:

\section{i. Length of national emergency period}

Since the enacting of the NEA in 1976, there have only been two presidentially declared public health emergencies - the H1N1 pandemic of 2009, which lasted for 364 days, and the ongoing COVID-19 pandemic (Brennan Center for Justice 2020). Considering a lack of precedent on the length of presidentially declared public health emergencies, Congress may consider the maximum length of 
"patent pause" under this policy as a potential negotiation point.

\section{ii. Licensing during patent pause}

A complete "patent pause" may burden patent holders that are small businesses compared to those that are large companies. In such cases, a "partial patent pause" may be a potential option, where licensing deals are provided to generic drug manufacturers at a discounted price. This may be a negotiating point for small businesses.

\section{iii. Double dipping}

If a patent approval is expedited during future national emergencies, patent term extensions under

\section{References}

Brennan Center for Justice. 2020. "Declared National Emergencies Under the National Emergencies Act Declaration." Brennan Center. January 26, 2021. https://www.brennancenter.org/ourwork/research-reports/declared-nationalemergencies-under-national-emergencies-act

Feuer, Will. 2021. "Here Are the 10 Executive Orders Biden Signed to Combat the Covid Pandemic." CNBC. January 21, 2021. https://www.cnbc.com/2021/01/21/biden-tosign-10-executive-orders-to-combat-covidpandemic-invoke-defense-production-act.html.

Government Publishing Office. 2020. "Federal Register." Federal Register. Washington, DC: Government Publishing https://www.govinfo.gov/content/pkg/FR2020-05-14/pdf/2020-10372.pdf.

Haeder, Simon F. 2019. "Why the US Has Higher Drug Prices than Other Countries." The Conversation. February 7, 2019. https://theconversation.com/why-the-us-hashigher-drug-prices-than-other-countries-111256.

House Committee on Energy and Commerce. 2020. "Hearing on 'Pathway to a Vaccine: Efforts to Develop a Safe, Effective and Accessible COVID-19 Vaccine' | Democrats, Energy and Commerce Committee." July 21, 2020. https://energycommerce.house.gov/committeeactivity/hearings/hearing-on-pathway-to-avaccine-efforts-to-develop-a-safe-effective-and.

Initiative for Medicines Access and Knowledge. 2018. "Solving the Drug Patent Problem." https://ssrn.com/abstract=2225781. the Hatch-Waxman Act would not apply, eliminating the chance of double dipping on extensions. However, existing products that qualify for a patent term extension under this policy may have previously received a patent term extension. Benefits in these cases may be another negotiation point.

If enacted, this policy may decrease drug costs and improve supply by temporarily removing monopolies created by patents. In an innovative industry such as the pharmaceutical sector, it is imperative that Congress innovates with the changing needs for governing (Markel 2013). The policy recommendation we provide in this memo may be an appropriate step towards fulfilling this need.

Inserro, Allison. 2020. "Gilead Sciences Sets US Price for COVID-19 Drug at $\$ 2340$ to $\$ 3120$ Based on Insurance | AJMC." American Journal of Managed Care. June 29, 2020. https://www.ajmc.com/view/gilead-sciencessets-us-price-for-covid19-drug-at-2340-to-3120based-on-insurance.

Johns Hopkins University. 2021. "Coronavirus Resource Center." February 15, 2021. https://coronavirus.jhu.edu/us-map.

Kaiser Family Foundation. 2020. "Public Opinion on Prescription Drugs and Their Prices ." Kaiser Family Foundation. October 16, 2020. https://www.kff.org/slideshow/public-opinionon-prescription-drugs-and-their-prices/.

Kapczynski, Amy, Paul Biddinger, and Rochelle Walensky. 2020. "Remdesivir Could Be in Short Supply. Here's a Fix. ." The New York Times. July 28, 2020. https://www.nytimes.com/2020/07/28/opinion $/$ remdesivir-shortage-coronavirus.html.

Lawson, Aidan, and June Rhee. 2020. "Usage of the Defense Production Act throughout History and to Combat COVID-19 | Yale School of Management." Yale School of Management. June 3, 2020. https://som.yale.edu/blog/usage-of-the-defenseproduction-act-throughout-history-and-tocombat-covid-19.

Lee Ventola, C. 2011. "The Drug Shortage Crisis in the United States Causes, Impact, and Management Strategies." $P$ and $T 36$ (11): 740-57. https://www.ncbi.nlm.nih.gov/pmc/articles/PM C3278171/

Lueck, Sarah. 2005. "'Bioshield' Drug-Patent Plan Draws Fire - WSJ." The Wall Street Journal. April 1, 2005. https://www.wsj.com/articles/SB11123112419 $\underline{7694876}$. 
Markel, Howard. 2013. "Patents, Profits, and the American People - The Bayh-Dole Act of 1980." New England Journal of Medicine 369 (9): 794-96. https://doi.org/10.1056/nejmp1306553.

National Archives. 2016. "Executive Orders | National Archives." Federal Register. August 15, 2016. https://www.archives.gov/federalregister/codification/executiveorder/12591.html.

O’Day, Daniel. 2020. "An Open Letter from Daniel O’Day, Chairman \& CEO, Gilead Sciences.” June 29, 2020. https://stories.gilead.com/articles/an-openletter-from-daniel-oday-june-29.

PhRMA. n.d. "Intellectual Property." Pharmaceutical Research and Manufacturers of America. Accessed November 13, 2020. https://www.phrma.org/en/Advocacy/Intellectu al-Property.

Richards, Kevin T., Kevin J. Hickey, and Erin H. Ward. 2020. "Drug Pricing and Pharmaceutical Patenting Practices,"

$1-45$. https://crsreports.congress.gov/R46221.

Schacht, Wendy H. 2009. "The Bayh-Dole Act: Selected Issues in Patent Policy and the Commercialization of Technology." Congressional Research Service, 28.

Schacht, Wendy H., and John R. Thomas. 2006. "CRS Report for Congress Bioterrorism Countermeasure Development: Issues in Patents and Homeland Security." Washington, DC.

Congressional Research Service. 2016. "The Hatch Waxman Act : A Primer."

Stevens, Ashley J. 2004. "The Enactment of Bayh-Dole." The Journal of Technology Transfer 29 (1): 93-99. https://doi.org/10.1023/b:jott.0000011183.408 $\underline{67.52}$.

Thomas, John R. 2016. "March-In Rights Under the BayhDole Act. CRS Report Prepared for Members and Committees of Congress." Congressional Research Service, R44597. https://fas.org/sgp/crs/misc/R44597.pdf.

U.S. Congress. 1984. "S.1538 - An Act to Amend the Federal Food, Drug, and Cosmetic Act to Revise the Procedures for New Drug Applications, to Amend Title 35, United States Code, to Authorize the Extension of the Patents for Certain Regulated Products, and for Other Purposes. | Congress.Gov| Library of Congress." September 24, 1984. https://www.congress.gov/bill/98thcongress/senatebill/1538?q=\%7B $\% 22$ search $\% 22 \% 3 \mathrm{~A} \% 22$ Drug+ Price+Competition+and+Patent+Term+Restorati on+Act $\% 22 \% 7 D \& s=2 \& r=3$.
U.S. Department of Health and Human Services. 2018. "Comparison of U.S. and International Prices for Top Medicare Part B Drugs by Total Expenditures." Washington DC. https://aspe.hhs.gov/system/files/pdf/187586/ Drugspendin.

U.S. Food and Drug Administration. 2020. "Small Business Assistance: Frequently Asked Questions on the Patent Term Restoration Program | FDA." February 4, 2020. https://www.fda.gov/drugs/cder-smallbusiness-industry-assistance-sbia/smallbusiness-assistance-frequently-asked-questionspatent-term-restoration-program.

U.S. Patent and Trademark Office. 2020a. "COVID-19 Prioritized Examination Pilot Program | USPTO." May 18, 2020. https://www.uspto.gov/initiatives/covid-19prioritized-examination-pilot.

U.S. Patent and Trademark Office.. 2020b. "Traditional Total Pendency by Technology Center ." September 2020. https://www.uspto.gov/dashboard/patents/tota l-pendency-by-tc.html.

Ways and Means Committee Staff. 2019. "A Painful Pill to Swallow : US vs . International Prescription Drug Prices Committee on Ways and Means," no. September. $\quad$ https://www.cms.gov/ResearchStatistics-Data-and-.

Weintraub, Karen, and Elizabeth Weise. 2020. “COVID Vaccine: US Government Spending \$9 Billion on Candidates." USA Today. August 10, 2020. https://www.usatoday.com/story/news/health/ 2020/08/08/feds-spending-more-than-9-billioncovid-19-vaccine-candidates/5575206002/.

Witters, Dan. 2020. "Nine in 10 Concerned About Rising Drug Costs Due to COVID-19." Gallup. June 18, 2020.

https://news.gallup.com/poll/312641/nineconcerned-rising-drug-costs-due-covid.aspx.

Wu, Katherine J. 2020. "Some Vaccine Makers Say They Plan to Profit From Coronavirus Vaccine - The New York Times." The New York Times. July 21, 2020.

https://www.nytimes.com/2020/07/21/health/ covid-19-vaccine-coronavirus-modernapfizer.html.

Aya W. Takai is a graduate of the University of Michigan School of Public Health and works as a legislative staffer in the United States Congress. 
Samuel B. Lum is a graduate of Rochester Institute of Technology and former biomedical engineering patent examiner in the United States Patent and Trademark Office. He is currently an engineer at the U.S. Food and Drug Administration, Center for Devices and Radiological Health.

\section{Acknowledgements}

The authors would like to express appreciation to William Bond, Conan Grames, and Sara Sass, Esq. for their comments on this publication.

\section{Disclaimer}

The views expressed herein are solely opinions of the authors and do not reflect the viewpoints of their employers or affiliations. 